\title{
FUNDAMENTAL KEWIRAUSAHAAN SEBAGAI MEDIA PENCIPTAAN LAPANGAN KERJA DI BIDANG FOTOGRAFI
}

\author{
Syamyatmoko \\ Dosen Program Studi Ilmu Komunikasi, Fakultas Ilmu Komunikasi, Universitas Islam Riau \\ Jalan Kaharuddin Nasution, Pekanbaru, Riau \\ No. Hp.: 081226460918,E-mail: syamyatmoko@gmail.com
}

\begin{abstract}
Abstrak
Lahir dari keajaiban teknologi dan terus berevolusi mengikuti jiwa zamannya, menegaskan bahwa fotografi adalah instrumen penghasil rupiah yang efektif. Terobosan berbagai media akhir guna display dan booming media sosial berbasis internet merangsang pertumbuhan pengguna fotografi, baik bersifat profesional maupun amatir. Terbukanya peluang besar untuk menciptakan lapangan kerja yang menjanjikan dan meningkatnya kebutuhan ilmu fotografi ditandai munculnya berbagai lembaga edukasi, komunitas, dan ruang diskusi. Memicu terjadinya persaingan ketat dalam medan bisnis fotografi, sebagian mencoba membangun dan jatuh, sebagian lagi tetap berproses demi sebuah mimpi. Satu dua orang telah menjadi raja, dan kebanyakan masih berkutat masalah teknis tanpa mampu merealisasikan peluang yang ada. Menciptakan lapangan kerja menurut para ahli sangat penting guna menekan angka pengangguran di suatu negara. Jika peluang terbuka lebar, seyogianya para insan fotografi ikut serta membantu pemerintah mewujudkannya, paling tidak mampu membuka lapangan kerja untuk dirinya sendiri. Menjadi seorang wirausaha di bidang fotografi bukan hal sulit, walaupun karena digitalisasi kompetitor semakin banyak, kesempatan selalu ada bagi yang mau menumbuhkan fundamental kewirausahaan dalam dirinya. Belajar dan mencoba adalah kunci untuk menjawab tantangan bisnis fotografi masa depan.
\end{abstract}

Kata kunci: fundamental, kewirausahaan, fotografi

\begin{abstract}
Entrepreneurship Fundamentals as Employment Creation Media in the Field of Photography. Born from the miracle of technology and continues to evolve following the spirit of its era, emphasizing photography as an effective instrument for earning money. The breakthrough in various user end media for display, as well as the booming of internet-based social media stimulate the growth of photography users both professional and amateur. The opportunity in creating promising employmens is widely opened, flagged by the blooming of education institution, community, and discussion forum. Hence, they trigger a tight competition in photography business, some may try and fail while some may keep on progress for the sake of their own dream. One or two may become successful, while others still work on the technique without being able to realize the given opportunity. Creating employment, according to some experts, is very important in lowering the unemployment in a country. When there is an opportunity, hopefuly the photographers could help the governemnt creating an employment opportunity, at least for themselves. Being an entrepreneur in photography is not really difficult, eventhough the numbers of competitors in digitalization is getting more each day,because an opportunity is always open for those who want to develop their own entrepreneur fundamental. Learning and trying are the keys to answer the challenge in photography business in the future.
\end{abstract}

Keywords: fundamental, entrepreneurship, photography 


\section{PENDAHULUAN}

Informasi merupakan esensi mengapa dokumentasi dibutuhkan. Sebuah foto dibuat secara sadar ataupun tidak menyimpan berbagai data mengenai objeknya. Data tersebut menjadi sumber informasi yang dapat dipersepsi dari berbagai sudut pandang, seperti semiotika, sejarah, estetika, hingga identitas. Kaya ragam informasi yang dimiliki sebuah foto menjadikannya sebagai kebutuhan penting bagi sebagian besar orang dansetiap kebutuhan akan menghasilkan pertukaran nilai. Perihal ini bukan hanya sekadar nilai finansial. Uang tidak pernah menjadi tujuan utama, namun perlu disadari tanpa uang kebutuhan sulit untuk dipenuhi. Jika ada transaksi, peluang untuk menciptakan lapangan kerja sangat besar.

Data terkini dari Global Entrepreneurship Monitor (GEM) menunjukkan bahwa Indonesia baru mempunyai sekitar 1,65 persen pelaku wirausaha dari total jumlah penduduk 250 juta jiwa (bisniskeuangan.kompas.com, diakses pada 5 Agustus 2016, pukul 19.40 WIB). Sementara Ciputra (Dr. Ir. Ciputra adalah seorang entrepreneur dan pendiri Universitas Ciputra Entrepreneurship Center) mengatakan, "Untuk membangun ekonomi bangsa dibutuhkan minimal $2 \%$ wirausahawan dari keseluruhan populasi” (entrepreneur.bisnis.com, diakses pada 5 Agustus 2016, pukul 22.13 WIB). Dengan demikian, Indonesia masih memerlukan sekitar 875.000 jiwa lagi calon wirausahawan. Data ini menjelaskan bahwa profesi sebagai wirausahawan masih terbuka lebar, serta tingginya kesenjangan jumlah jika dibandingkan dengan keseluruhan penduduk. Artinya jumlah permintaan akan lebih banyak dari penawaran, dari 250 juta jiwa hanya 5 juta jiwa yang berprofesi wirausaha, masih ada sekitar 245 juta jiwa yang bakal menjadi konsumen.
Sebuah ilustrasi jika data ini digunakan dalam kebutuhan fotografi, akan didapati gambaran bahwa ada 250 juta pasfoto yang dibutuhkan dan ada 5 juta fotografer, berarti ada sharing profit sekitar 50 juta pasfoto untuk tiap fotografer, apabila dalam 1 hari seorang fotografer dapat mengerjakan 50 klien, dibutuhkan sekitar 27 abad untuk menyelesaikannya. Akan tetapi, itu semua hanya sekadar perhitungan awam. Realitanya studio foto kebanjiran permintaan pasfoto hanya pada saat pergantian tahun ajaran baru. Hal ini menjelaskan bahwa wirausaha selalu berdampingan dengan ambiguitas, tidak ada kepastian atas segala sesuatunya. Sangatlah bijak seorang wirausahawan selalu mendekatkan diri kepada Tuhan. Dialah yang memberi rezeki, manusia hanya sebatas mencari dan berusaha. Wira berarti pejuang dalam bahasa Sanskerta. Seorang wirausahawan adalah pejuang yang berusaha demi tujuannya, dan tidak takut akan ketidakpastian.

Pasfoto hanyalah satu dari sekian banyak kebutuhan manusia atas fotografi, berarti peluang bisnis di bidang fotografi sangat besar. Peluang sebenarnya sangat mudah dibaca, hanya saja setiap peluang akan menghasilkan risiko. sejalan dengan pengertian entrepreneur menurut Serian bahwa pada dasarnya kata tersebut digunakan untuk mengambarkan orang-orang yang berani mengambil risiko dan memulai sesuatu yang baru (Serian, 2009:2). Wirausaha atau entrepreneur dalam persamaan bahasa asing menjelaskan bahwa wirausahawan selalu berurusan dengan risiko. Hal ini yang menyebabkan ketidakseriusan setiap orang mau melihat peluang dan merealisasikannya. Dengan demikian, minimnya pertumbuhan wirausaha baru di Indonesia, jika dibandingkan dengan negara maju lain yang telah mencapai 
angka $7 \%$ dari populasi penduduk. Negara Indonesia sangat jauh tertinggal.

Risiko tidak dapat dihindari, tetapi masih bisa diminimalisasi. Penting sekali menumbuhkan pemahaman-pemahaman kewirausahaan sebagai motivasi dan panduan menghadapi segala hambatan sehingga memungkinkan rendahnya risiko yang mungkin terjadi. Kewirausahaan bukan hal yang mudah dicerna secara teori. Pada hakikatnya ilmu ini hanya bekerja jika diaplikasikan lewat praktikum. Risiko yang nyata hanya datang jika ada tindakan praktik wirausaha karena tanpa tindakan nyata risiko hanya menjadi sebatas imajinasi. Risiko selalu dipahami dari sisi negatif, seperti halnya kata kritik dipandang sebagai alat mencari kelemahan, risiko sebenarnya adalah diafragma dari keuntungan. Perihal ini menjelaskan mengapa ada seseorang yang mau berprofesi sebagai pencari risiko. Memahami konsep risiko sama saja dengan berinvestasi atas keuntungan nilai masa depan.

Pertumbuhan wirausaha di Indonesia tertinggal jauh dari negara lain, begitu juga sumbangsih fotografi dalam perputaran ekonomi kreatif. Dari tabel 1 bisa dijelaskan bahwa fotografi menyumbang sebesar 8,4 triliun atau $1,3 \%$ dari total nilai tambah ekonomi kreatif 2013. Persentase yang sangat kecil jika dibandingkan dengan 9 bidang lainnya. Padahal fotografi adalah profesi terbuka dan sangat banyak peluang yang bisa dihasilkan. Hal ini disebabkan rendahnya minat para fotografer terhadap kewirausahaan dan juga didorong minimnya pembekalan ilmu serta penanaman fundamental kewirausahaan.
Tabel 1

Nilai Tambah Bruto Sub-sektor Ekonomi Kreatif 2010-2013

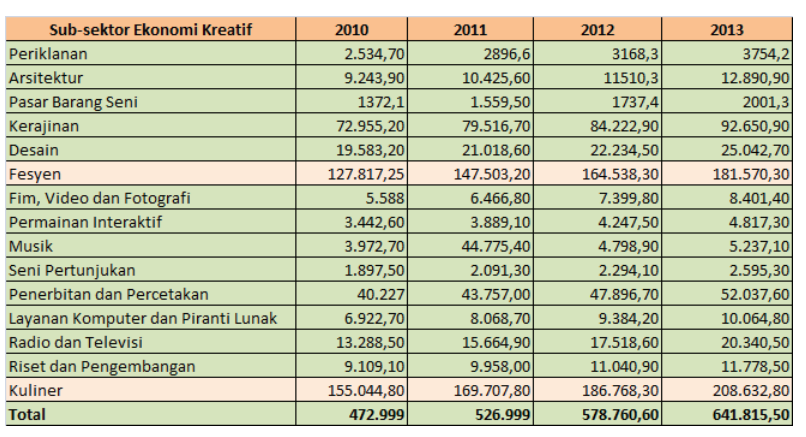

(Sumber : Badan Pusat Statistik, 2013)

Kewirausahaan bukan hanya cara menghasilkan uang. Para ahli menyebutnya sebagai mesin pembangunan ekonomi negara, serta salah satu jalan mendekatkan diri kepada sang pencipta. Begitu juga fotografi sebagai media seni, Arifin C.Noer (Tokoh seni teater dan perfilman Indonesia) pernah berkata,"Kesenian saya bukanlah uang" (perfilman.perpusnas. go.id, diakses pada 12 Agustus 2016, pukul 11.56 WIB). Seni memandang uang bukanlah segalanya, tetapi tanpa uang seseorang tidak pernah bersungguh-sungguh bertaruh atas risiko, tidak ada risiko berarti tidak ada produktivitas, dalam hal ini karya suatu seni. Jadilah fotografer yang siap mengambil risiko, serta memiliki fundamental kewirausahaan guna menciptakan nilai pada masa depan.

\section{FUNDAMENTAL KEWIRAUSAHAAN}

Menciptakan generasi muda yang memiliki kepribadian wirausaha, saat ini merupakan solusi terbaik untuk meningkatkan perekonomian nasional. Membentuk pribadi seperti ini dibutuhkan proses panjang karena kesalahan paradigma yang dibiarkan terlalu lama menghambat pertumbuhan kewirausahaan. Perlu sedini mungkin mengenalkan berbagai faktor landasan kewirausahaan. Kebanyakan orang malah menganggapnya sebagai hambatan, 
padahal faktor-faktor ini tidak pernah dapat dipisahkan dari kegiatan wirausaha, sepeti modal, inteligensi, bakat, risiko, dan ambiguitas.

Dalam Kamus Besar Bahasa Indonesia dijelaskan bahwa fundamental adalah bersifat dasar (pokok). Seseorang dengan fundamental kewirausahaan harus memahami esensidan mengenali keterkaitan antara tiap-tiap faktor dasar terhadap proses pembentukan wirausahawan, di antaranya:

1. Modal

Sejumlah uang sangat penting untuk memulai sebuah usaha karena uang adalah sumber modal utama yang mendanai produktivitas, permasalahan klasik yang dialami hampir semua calon wirausahawan. Sumber modal bisa berasal dari modal mandiri ataupun modal asing. Kedua sumber ini memiliki keunggulan dan kelemahan masing-masing. Modal mandiri berarti mempertaruhkan kehidupan pribadi yang sifatnya terbatas, tidak memiliki beban, dan bebas syarat, sedangkan modal asing memanfaatkan sumber daya luar yang tidak memiliki batas, menimbulkan beban dengan persyaratan rumit.

Kombinasi antara keduanya sangat tepat untuk membangun sebuah usaha karena memiliki jumlah yang besar dengan rendah beban, dan tumbuhnya motivasi kerja dipicu oleh tanggung jawab moral terhadap pertaruhan risiko atas modal orang lain. Permasalahan yang sering timbul adalah para pemula tidak memiliki modal mandiri dan tidak mengerti cara mendapatkan kepercayaan modal asing. Mendapatkan investasi dari luar sebenarnya tidaklah sulit karena diperlukan modal pendukung untuk itu. Selain modal uang, seorang wirausahawan juga harus mempunyai modal inteligensi. Dua jenis modal ini saling terkait satu sama lain. Seseorang bisa saja membangun usaha jika memiliki sejumlah dana, tetapi jika itu dilakukan tanpa bantuan inteligensi usaha tersebut tidak akan bernilai pada masa depan.

Investasi bertujuan untuk mendapatkan sejumlah keuntungan pada masa yang akan datang. Untuk mendapatkan modal asing diharuskan memenuhi sejumlah persyaratan. Di sinilah calon wirausahawan dituntut menentukan konsep, kerangka pikir, dan prediksi nilai masa depan. Hal ini akan menghasilkan sebuah perencanaan usaha. Buatlah perencanaan yang mudah dimengerti orang lain karena semakin mudah dipahami, maka semakin besar juga ketertarikan calon investor.

Dengan sebuah perencanaan usaha seorang calon wirausahawan dapat mengajukan pendanaan baik itu berupa hibah, hadiah kompetisi, dan pinjaman. Sayangnya investor seperti lembaga keuangan dan instansi terkait akan menyetujui jika usaha telah berjalan selama dua tahun, sedangkan untuk hadiah kompetisi bisa saja itu baru berupa konsep, tetapi setiap konsep harus diuji melewati berbagai tahapan. Hal paling realistis adalah dengan mengajukan perencanaan kepada orang-orang terdekat yang memiliki sejumlah dana yang dibutuhkan. Orang ini bisa saja keluarga dan teman dekat yang telah sukses.

Berkembangnya berbagai kebutuhan manusia menyebabkan terbukanya peluang usaha yang membutuhkan sedikit 
dana, seperti makelar dan penjual online. Saat ini membuka usaha fotografi tidaklah susah, di beberapa kota besar kini juga sudah tersedia jasa-jasa penyewaan kamera, peralatan, dan studio foto. Perkembangan media sosial berbasis internet juga membantu fotografer untuk sekadar berbagi karya, membuat jejaring, dan menghasilkan uang. Sebenarnya infrastruktur sudah berjalan dengan baik hanya mental dan minat menjadi usahawan yang masih sangat rendah. Modal bukanlah permasalahan yang krusial dengan sedikit mengubah pola pikir sebuah usaha bisa dibangun.

\section{Inteligensi}

Kesombongan manusia membuat dirinya merasa selalu yang paling pintar, maka gunakanlah kepintaran untuk menciptakan nilai yang bisa dijual. Kenyataannya banyak orang pintar, tetapi tidak tahu cara menghasilkan sebuah usaha. Semakin pintar seseorang, semakin mudah baginya membaca kemungkinan setiap risiko yang ada. Hal ini menyebabkan menurunnya minat seseorang untuk merealisasikan gagasan usaha yang dimiliki.

Banyak orang berpikir butuh sebuah keahlian untuk membangun suatu usaha. Hal ini benar adanya karena tanpa keahlian menemukan peluang dan keahlian merealisasikannya akan terasa sangat sulit sekali karena dua keahlian tersebut akan menciptakan nilai yang layak dikonsumsi. Keahlian selebihnya hanyalah tranportasi yang membawa wirausahawan terhadap minatnya. Kasali (2011:110) menyatakan bahwa "Kalau ingin membuka usaha, mulailah dari bidang yang paling diminati". Minat menjadi wirausahawan saat ini sangat penting, tetapi minat terhadap usaha yang akan dibangun jauh lebih penting guna keberlangsungan. Seseorang membuka usaha tanpa minat diibaratkan seperti roda, usahanya akan terus bergerak mengelilingi dunia, tetapi tidak pernah naik tingkat karena habis ke atas langsung ke bawah lagi.

Wirausahawan dengan minat akan memiliki kecintaan terhadap apa yang ia bangun. Motivasinya tidak hanya uang, tetapi ada bentuk kebutuhan berupa aktualiasasi diri. Terkadang seorang karyawan menanggalkan kontrak kerjanya di kantor untuk menjadi musisi seperti penyanyi Tompi. Ini adalah bentuk dari aktualisasi diri terhadap minatnya. Orang yang bekerja dengan minat akan memiliki kemampuan bertahan yang baik, seperti pendaki gunung. Pada saat lelah dia harus berhenti dan bersabar sambil menyusun kekuatan baru, terkadang mengambil rute yang salah dan harus mencari rute yang baru atau turun. Cadas dan jurang adalah risiko untuk ditempuh, tetapi kecintaan memberi keyakinan bahwa usahanya akan sampai ke atas gunung.

Inteligensi selalu dikaitkan dengan suatu keahlian dan mampu menganalisis segala sesuatu sehingga mampu memprediksi masa depan. Sayangnya kepintaran selalu membawa orang lebih jauh ke depan. Terlalu mudah untuk melihat peluang, begitu juga dengan risikonya, akhirnya gagasan usaha hanya sebatas imajinasi. Pandangan sederhana para ahli kewirausahaan tentang goblok sangat relevan dengan permasalahan ini. 
Sadino (haji.tempo.co, diakses pada 29 Agustus 2016, pukul 10.27 WIB) berkata, "Orang goblok cenderung tidak banyak pertimbangan, nothing to lose, karena memang tak punya daya analisis". Orang pintar akan selalu terbebani oleh banyak pertimbangan, sedangkan orang goblok hanya bisa meneruskan satu pilihan tanpa mengetahui risiko apa yang akan ditempuh.

Minat berwirausaha bisa dimotivasi seperti halnya pandangan ini. Mampu memotivasi bahwa tidak perlu menjadi pintar untuk berwirausaha, jadilah bodoh untuk melihat berbagai risiko agar memiliki mental merealisasikan gagasan usaha. Jadilah bodoh agar bisa terus belajar dari kegagalan dan jadilah pintar karena pengalaman.

3. Bakat

Dilahirkan dalam keluarga wirausahawan tidak menjamin seseorang juga berbakat berwirausaha. Profesi tertentu sering dikaitkan dengan etnis tertentu, dalam hal ini wirausaha identik dengan Tionghoa. Akan tetapi, akhir-akhir ini beberapa warga Indonesia keturunan Tionghoa memilih berprofesi di jalur politik. Begitu juga sebaliknya seseorang yang besar di lingkungan pegawai tidak menutup kemungkinan menjadi wirausahawan. Hal ini dikarenakan kewirausahaan bukan pengaruh DNA. Bakat adalah sesuatu yang bisa dilatih, tetapi melatih orang yang berbakat akan lebih mudah.

Sebagai ilustrasi, seorang dengan penyakit gagap berbicara, selalu terlihat tertutup tidak banyak bicara. Hal ini dikarenakan ketakutannya jika orang mengetahui kekurangannya. Sulit baginya untuk berkomunikasi dengan orang lain apalagi dengan banyak mata yang memerhatikan, apalagi bercita-cita menjadi seorang pembicara. Dalam proses pembelajaran dia menemukan bakat yang bernilai dari kelemahannya, tanpa disadari dia mampu membuat orang lain tertawa dengan berbicaranya yang gaga. Hal ini membuatnya mudah dikenali dan selalu mendapat perhatian dari banyak orang. Berkat latihan dan berproses panjang, kini dia bekerja sebagai seorang tenaga pengajar. Setiap tahun dia harus berhadapan dengan ribuan pasang mata yang memerhatikannya.

Ilustrasi ini mungkin hanya cerita fiktif, tetapi kenyataannya banyak contoh orang yang tidak memiliki bakat dapat berhasil di bidangnya. Hal ini menegaskan bahwa bakat dapat dilatih, seorang yang gagap mungkin tidak bisa jadi pembicara, tetapi saat ini dia mampu menghasilkan uang hanya dengan berbicara. Wirausaha adalah hal yang bisa dilatih, begitu juga dengan fotografi. "Entrepreneur dapat diajarkan, dan seseorang dapat dididik menjadi entrepreneur, tidak memandang latar belakangnya" (Riant, 2009:128). Pandangan ini menjelaskan bahwa kewirausahaan merupakan profesi terbuka yang dapat diajarkan, seperti halnya fotografi yang bisa dipelajari dan diajarkan. Akan tetapi, penting sekali mempelajari konsep kewirausahaan melalui praktikum nyata membuka kegiatan usaha, seperti halnya mempelajari teknik fotografi tanpa menyentuh kamera adalah hal yang absurd. 
4. Risiko

Peluang akan menghasilkan risiko, tetapi setiap risiko akan menghasilkan keuntungan. Sebuah teori manajemen menjelaskan konsep sederhana mengenai risiko, Hi Risk Hi Return, Low Risk Low Return, yaitu ada risiko yang tinggi akan menghasilkan keuntungan yang tinggi pula. Begitu juga sebaliknya, risiko yang rendah juga menghasilkan keuntungan yang rendah pula.

Akhir-akhir ini sering terdengar pemberitaan seorang pengedar narkoba yang sampai dihukum mati. Seorang pengedar hanya membutuhkan tas ransel kecil untuk membawa $3 \mathrm{~kg}$ narkoba yang bernilai setara 300 ton tepung terigu, sedangkan penjual tepung terigu membutuhkan sebuah kontainer untuk menyimpan seluruh barangnya. Risiko yang dihasilkan juga berbedakarena pengedar narkoba harus mempertaruhkan nyawa, sedangkan penjual tepung hanya mempertaruhkan modal, perihal paling buruk yang akan dialami adalah kebangkrutan.

Fotografer pembuat foto potret memiliki risiko yang berbeda dengan pembuat pasfoto, padahal jika dipandang dari ciri-ciri kedua foto ini tidaklah jauh berbeda, hanya peruntukan kebutuhan saja yang menjadi pembedanya. Foto potret diperuntukkan guna menonjolkan profil seseorang dalam sebuah foto, butuh kedekatan antara fotografer sebagai pembuat, terkadang harus menggunakan berbagai teknik pencahayaan yang rumit, ditambah dengan beberapa properti pendukung yang menjadi ciri khas seorang objek. Makanya foto potret harganya lebih mahal daripada membuat pasfoto yang diperuntukkan untuk tanda pengenal. Keuntungan yang lebih besar pasti diikuti risiko yang besar pula. Tidak semua fotografer sukses membuat foto potret, terutama bagi mereka yang tidak mampu menjelajahi karakteristik dari kliennya. Pembuat foto ini akan selalu berdekatan dengan komplain, tidak jarang juga harus mengembalikan sejumlah uang ganti rugi.

Jika mengharapkan untung yang besar, seorang wirausahawan harus berani mengambil risiko yang besar. Menghindari risiko sama saja berhenti untuk mendapatkan keuntungan.Risiko hanya bisa diminimalisasi dengan kualitas kerja dan pengetahuan menciptakan nilai. Kenalilah segala risiko yang mungkin kita hadapi, karena bisnis adalah mengelola risiko (Kasali, 2011:184). Mengenali risiko akan memudahkan wirausahawan mengenali setiap kualitas yang dibutuhkan konsumen. Jika kebutuhan nilai telah terpenuhi, keuntungan akan datang dengan sendirinya.

\section{Ambiguitas}

Setiap manusia selalu menginginkan kepastian dalam hidupnya. Mereka ingin pasti memiliki pekerjaan, jodoh, keturunan, kekayaan, dan kekuasaan. Sebagai hakikat hidup semua orang mengerti bahwa setiap makhluk hidup pasti mati, selebihnya hanyalah sebuah misteri, ketidakpastian adalah kehendak Tuhan sebagai pencipta yang mengatur kehidupan semua makhluk-Nya. Jika semuanya serba pasti niscaya kepercayaan terhadap-Nya hanyalah dongeng 
pengantar tidur, ketidakpastian adalah kodrat yang harus dilalui manusia semasa hidupnya.

Hidup berwirausaha berarti hidup di dalam ketidakpastian. Ketika membuka usaha fotografi, seseorang tidak dapat memprediksi siapa saja konsumennya, apakah mereka memiliki minat menggunakan jasa yang ditawarkan, maukah mereka melakukan order ulang, dan berbagai pertanyaan lain tentang ketidakpastian. Orang yang memiliki jiwa kewirausahaan tidak menyukai kepastian karena sesuatu yang pasti sangat mudah ditebak. Pada saat konsumerisme gaya hidup telah menjadi kebutuhan global, setiap orang membutuhkan kejutan berupa keuntungan yang besar, untung selalu terkait dengan risiko. Tidak setiap risiko besar juga mendatangkan keuntungan yang besar karena semua tidak ada yang pasti. Disinilah keagungan Tuhan terlihat, manusia itu adalah makhluk yang lemah dan butuh pertolongan-Nya untuk sebuah keberuntungan.

Banyak ahli berpendapat keberuntungan adalah hasil dari kerja keras. Pandangan ini juga belum tentu pasti, banyak orang hidup dari keberuntungan tanpa kerja keras, seperti anak konglomerat, pemenang undian, dan artis sensasional. Tidak ada yang pasti dalam hidup ini selain kematian. Ketidakpastian adalah cara mendekatkan diri kepada Tuhan. Keberuntungan selalu datang untuk mereka yang siap hidup dalam ketidakpastian.

Berkembangnya kebutuhan manusia atas fotografi merupakan pintu bagi setiap fotografer untuk mengaktualisasikan ilmunya kedalam wirausaha. Penting sekali memahami berbagai faktor landasan yang menjadi penentu terbentuknya fundamental kewirausahaan. Membangun usaha fotografi membutuhkan modal yang besar karena fotografi sangat erat dengan perkembangan teknologi. Tanpa modal uang akan terasa sangat sulit merealisasikannya sehingga dibutuhkan juga modal pendukung berupa intelegensi guna menganalisis setiap permasalahan. Dengan memanfaatkan inteligensi fotografer dapat meminjam sumber daya dari luar untuk memfasilitasi berbagai kebutuhan dalam membangun usaha. Intelegensi disini sering dikaitkan dengan keahlian atas suatu bidang. Para pemula selalu dihantui oleh rasa malu karena kemampuan fotografinya tidak mumpuni sehingga menyebabkan tidak memiliki keinginan mencoba peruntungan di bidang fotografi. Padahal keahlian yang terpenting adalah bagaimana menemukan peluang dan merealisasikanya dengan memanfaatkan sumber daya dari luar.

Kebanyakan orang beralasan bahwa mereka tidak memiliki bakat berwirausaha karena berasal dari keluarga pegawai. Bakat bukan DNA keturunan karena sejatinya bakat adalah proses latihan terhadap minat di suatu bidang. Siapa saja bisa berbakat menjadi wirausahaan jika mau menempuh latihan panjang merintangi risiko dan kehidupan ambiguitas. Manusia hidup untuk memenuhi takdirnya, risiko dan ambiguitas adalah takdir yang harus dijalani tiap orang. Setiap tindakan, sikap, dan perkataan akan menghasilkan risiko. Manusia juga tidak tahu apa yang akan terjadi esok hari, ketidakpastian telah dijalani dari kecil. Disadari ataupun tidak sebenarnya manusia selalu bertemu dengan risiko dan ambiguitas. Jika kewirausahaan menawarkan 
hal yang sama, mengapa minat kewirausahaan begitu rendah? Permasalahan ini hanya bisa diselesaikan dengan penanaman fundamental kewirausahaan sedini mungkin, semakincepat mengenali dan memahami konsep-konsep landasan, semakin mudah menumbuhkan pribadi yang bermental wirausaha.

\section{MENEMUKAN PELUANG DAN STRATEGI BERWIRAUSAHA}

Setiap hari manusia bertemu dengan peluang. Hanya saja keinginan untuk mendapatkannya masih sangat rendah, peluang bisa saja hadir dari suatu masalah dalam masyarakat, terutama masalah-masalah yang memiliki penyelesaian. Kasali (2011:130) menyebutkan "Peluang itu dapat timbul dengan sendirinya kalau kita telah mempersiapkan diri untuk untuk menangkapnya. Dengan kata lain, masalah akan menjadi peluang kalau manusia mempersiapkan diri untuk mendapatkannya". Daerah terpencil yang kaya akan wisata alam dan sejarah namun minim publikasi adalah masalah dalam meningkatkan sumber devisa negara, perihal ini merupakan peluang yang dimanfaatkan fotografer travelling seperti Barry Kusuma (Kontributor Getty Image Indonesia danTravel Photo Blogger), menjadi fotografer travelling tidaklah mudah karena dituntut untuk melakukan persiapan dan riset mengenai objek yang akan diangkat, Barry juga mengatakan "Menjadi fotografer travel pun butuh persiapan yang matang setiap harinya" (cnnindonesia. com, diakses pada 3 Agustus 2016, pukul 11.03 WIB). Mempersiapkan diri terhadap berbagai kemungkinan sangat dibutuhkan seorang wirausahawan karena permasalahan selalu terjadi setiap hari, tiap ada masalah pasti akan menghasilkan peluang.

Awal tahun ajaran baru setiap siswa membutuhkan pasfoto guna registrasi ulang sehingga pemintaan pasfoto biasanya juga meningkat. Hal ini dapat dijadikan momen fotografer menciptakan peluang. Dari pasfoto bisa saja melebar menjadi proyek buku tahunan ataupun profil sekolah. Kemampuan memenuhi kebutuhan adalah peluang nyata menghasilkan nilai masa depan Jangan meremehkan kebutuhan sederhana karena dia juga dapat menimbulkan kebutuhan baru lainnya. Peluang juga dapat lahir dari sebuah imajinasi, Angki Purbandono, Direktor Ruang Mes 56 dan pendiri PAPs (Prison Art Programs), seorang seniman fotografi yang berhasil menggunakan imajinasinya untuk menghasilkan peluang. Jenis peluang ini biasanya menawarkan pembaharuan sehingga memiliki nilai sangat tinggi. Keuntungan yang tinggi selalu dikaitkan dengan risiko yang tinggi pula. Setiap pembaruan belum tentu bisa diterima oleh masyarakat. Butuh proses pengenalan manfaat dan uji kelayakan yang panjang agar dapat diterima. Jika gagasan ini sudah mendapatkan respons yang baik, peluangnya sangat besar dikarenakan kompetisi sejenisnya tidak ada.

Menemukan peluang yang sesuai dengan minat bagi pemula memang agak sulit, dibutuhkan umpan balik dari berbagai gagasan peluang, untuk itu seorang wirausahawan dituntut memilki mentor. Mendiskusikan ide dengan seseorang yang telah memiliki pengalaman wirausaha sangat dianjurkan karena pengalamannya dapat menuntun ke jalan yang paling efektif dan efisien untuk mewujudkan peluang. Terkadang ide usaha brilian bisa muncul dari pandangan mereka yang telah lebih dulu memulai. Minimalisasi risiko sangat mungkin terjadi karena sejumlah risiko juga sudah dilalui mereka. Perihal ini sangat baik bagi pemula yang terlalu memikirkan risiko. 
Memanfaatkan peluang orang lain untuk ditiru juga dibisa dilakukan untuk membangun sebuah usaha, para ahli menjelaskan prinsip amati, tiru, dan modifikasi (ATM). Prinsip ini sangat efektif bagi pemula. Peluang yang telah digunakan orang lain berarti sudah mengalami berbagai ujian sehingga mudah diterima konsumen. Perihal ini memudahkan dalam menurunkan risiko atas rendahnya minat para pengguna. Lakukan pengamatan atas usaha orang lain yang sesuai dengan minat, kemudian tiru segala aspek yang mungkin bisa digunakan dan buatlah modifikasi atas peluang tersebut. Modifikasi sangat penting guna menjadi pembeda usaha dengan orang lain. Selain itu, kebaruan adalah kebutuhan yang dibutuhkan konsumen saat ini.

Setelah berbagai cara mendapat peluang ditempuh perlu menerapkan berbagai strategi untuk mengembangkan usaha. Adapun strategi berwirausaha tersebut berupa menciptakan nilai, keunikan, penetrasi harga, dan layanan prima. Berfokus menciptakan nilai produk ataupun jasa yang ditawarkan dengan melakukan inovasi. Berbisnis tidak harus selalu dimulai dengan membuat produk. Kita dapat memulai bisnis dengan menciptakan nilai, yaitu membuat pasar menghendaki kita (Kasali, 2011:44). Produk yang ditawarkan bisa saja sama dengan orang lain, tetapi dengan penyampaian yang inovatif sebuah produk akan memiliki nilai tambah dan berdampak pada kepuasan konsumen. Saat ini hampir semua fotografer pernikahan menawarkan produk yang sama sehingga perlu melakukan inovasi dalam penyampaiannya. Perihal ini seperti memberikan layanan pembayaran yang bisa dicicil dalam kurun waktu tertentu.

Menciptakan keunikan suatu produk sama pentingnya dengan menciptakan nilai atas sebuah produk. Akan tetapi, kedua hal ini sangat berbeda karena keunikan akan berdampak pada karakteristik ataupun identitas dari produsen. Dengan keunikan, konsumen bisa dengan mudah membedakan produk. Darwis Triadi (Fotografer Fashion dan Glamor, serta pendiri Darwis Triadi School of Photography) belakangan ini lebih banyak memanfaatkan pencahayaan alami yang dipadu dengan cahaya buatan nonfotografi seperti lampu neon. Padahal kebanyakan fotografer menggunakan cahaya tambahan yang merupakan peralatan pendukung fotografi. Sumber cahaya yang berbeda akan menghasilkan efek pencahayaan berbeda pula sehingga calon konsumen juga mudah membedakan antara karya Darwis Triadi dengan fotografer lainnya.

Menentukan ceruk pasar sangat vital untuk kesuksesan dalam membangun sebuah usaha. Hal ini sejalan dengan pendapat Eka (2014:64) bahwa "Salah satu cara untuk meningkatkan kemungkinan sukses adalah dengan menggambarkan pasar yang tepat". Ceruk pasar yang baik adalah ceruk paling terkecil dan khusus, yaitu hanya berfokus memenuhi kebutuhan segemen kecil tertentu. Ada banyak manfaat yang bisa dihasilkan dari penentuan ceruk pasar, di antaranya telah melakukan riset pasar sederhana. Untuk mengamati ceruk pasar dibutuhkan banyak data mengenai sasaran pasar, terutama data demografi dari calon konsumen. Untuk membuat riset pasar dibutuhkan banyak biaya, tetapi dengan menentukan ceruk pasar berarti sudah melakukan efisiensi dalam usaha.

Berfokus pada ceruk pasar tertentu juga dapat menekan biaya yang digunakan untuk pemasaran. Biaya terbesar bagi para pemula adalah biaya untuk promosi karena tanpa promosi orang tidak akan pernah tahu apa yang 
ditawarkan. Lakukan penghematan dengan ceruk pasar terkecil. Semakin kecil ceruk pasar yang diinginkan, semakin mudah untuk menyediakan layanan yang berkualitas. Karena hanya melayani sejumlah konsumen, seluruh energi dapat diserap oleh konsumen untuk menghasilkan kualitas. Semakin banyak orang yang dilayani, semakin besar energi dibutuhkan. Perihal ini akan membuat kewalahan untuk menciptakan pelayanan berkualitas.

Sebagai pendatang baru sangat bijak melakukan penetrasi harga guna menarik minat pelanggan. Konsep sederhana yang ditawarkan pandangan wirausahawan klasik, jika tidak bisa menjual lebih murah, paling tidak menjual dengan harga yang sama. Sejumlah ahli mempunyai pandangan berbeda dengan konsep ini. Apabila telah menemukan keunikan dan nilai maka menaikkan harga sangat memungkinkan.Banyak pemula salah dengan menentukan harga jual yang terlalu rendah hanya untuk mendapatkan pelanggan. Melalukan penetrasi harga untuk jangka waktu lama akan merusak standardisasi harga, namun perlu diingat bahwapenting mendapatkan klien pertama untuk modal produksi selanjutnya, maka fokuslah memikirkan cara guna mendapatkan pelanggan pertama. Fotografi adalah pertukaran nilai jasa. Karena jasa bukan hal yang mudah dikalkulasikan, fotografi memiliki kesenjangan antara biaya produksi dan keuntungan. Jadi, harga termurah yang ditawarkan tidak akan menimbulkan kerugian finansial. Akan tetapi, jika perihal ini terlalu lama dilakukan akan berdampak buruk bagi perkembangan usaha sendiri dan orang lain.

Salah satu kunci keberhasilan meningkatkan kepuasan konsumen adalah dengan memberikan layanan yang berkualitas sehingga perlu bagi para wirausahawan untuk mewujudkannya. Pada saat kompetisi usaha di bidang fotografi semakin banyak karena pengaruh digitalisasi, maka penting sekali memenangkan persaingan pasar. Program layanan yang berpijak kepada konsep kepedulian terhadap konsumen terus dikembangkan dalam perusahaan. Saat ini program tersebut menjadi salah satu alat utama dalam melaksanakan strategi pemasaran untuk memenangkan persaingan (Barata, 2003:25).

Ada beberapa faktor dimensi layanan yang dapat meningkatkan kualitas dari sebuah layanan, yaitu: (1) berwujud (tangibles): dimensi ini menggambarkan layanan fasilitas fisik, seperti tatanan desain interior, mesin kasir berteknologi digital, ruang tunggu yang memadai, juga kebersihan toko adalah hal yang tampak oleh konsumen. Penting sekali memerhatikan serta membenahi segala faktor fisik yang dapat menunjang pelayanan; (2) keandalan (reliability): merujuk pada kemampuan seorang fotografer untuk memberikan pelayanan yang dijanjikan secara akurat dan handal. Setiap permasalahan yang muncul dalam praktik fotografi harus dapat diselesaikan dengan cepat dan tepat, bekerja secara profesional dan terus mendalami hal-hal bersifat teknis fotografi akan mewujudkan pelayanan terbaik dalam dimensi ini; (3) responsif (responsiveness): kesediaan untuk membantu serta memberikan perhatian yang tepat merupakan bentuk respons positif kita terhadap pelanggan, hal-hal sederhana seperti menyambut pelanggan ketika berkunjung, membuka komunikasi dengan pertanyaan ringan, dan segera menangapi segala bentuk keluhan maupun permintaan merupakan perwujudan responsif dari sebuah pelayanan; (4) kepastian (assurance):sudah menjadi kebutuhan manusia atas kepastian, untuk itu dituntut dapat memberikan rasa percaya serta keyakinan 
terhadap pelanggan. Berbagai perusahaan besar memberikan jaminan pengembalian uang jika produk tidak sesuai dengan ekspektasi klien. Jika menginginkan usaha naik kelas, mental perusahaan besar seperti ini harus dimiliki. Memberikan jaminan yang maksimal akan berdampak pada peningkatan jumlah permintaan; (5) empati (emphaty): kepedulian serta perhatian seorang wirausahawan kepada konsumennya dapat meningkatkan kualitas pelayanan, dengan sedikit bantuan kecil yang sebenarnya bukan urusan kita dapat menumbuhkan hubungan baik dengan klien. Jika hubungan telah terbangun, klien akan loyal. Hal ini akan menghemat biaya promosi karena salah satu fungsi promosi adalah untuk mengingatkan kembali produk atau jasa terhadap klien.

\section{SIMPULAN}

Fotografi saat ini telah menjadi kebutuhan publik sehingga terbuka peluang besar bagi pengguna fotografi untuk menciptakan lapangan kerja. Akan tetapi, sangat disayangkan peluang ini tidak dimanfaatkan maksimal karena minat seseorang terhadap profesi kewirausahaan sangat rendah. Padahal, kewirausahaan dapat membantu negara dalam peningkatan ekonomi nasional. Wirausaha juga salah satu cara mendekatkan diri terhadap Sang Pencipta.

Rendahnya minat karena kesalahan paradigma yang menganggap bahwa berwirausaha itu sulit, harus sedini mungkin dibenahi dengan mengenalkan fundamental kewirausahaan kepada masyarakat. Seorang dengan fundamental kewirausahaan akan memiliki mental yang tangguh karena mereka memahami segala macam faktor yang menghambat, serta mampu mengoptimalkan faktor-faktor tersebut hingga menjadi kekuatan untuk membangun sebuah usaha.

\section{KEPUSTAKAAN}

Barata, Atep A. 2003. Dasar-Dasar Pelayanan Prima.Jakarta: Penerbit PT Elex Media Komputindo, Gramedia.

Eka, Ebong. 2014. Start Me UP.USA: Published The Career Press. Alih Bahasa Indonesia. Dicetak PT Tiga Serangkai Pustaka Mandiri, Solo.

Kasali, Rhenald. 2011.Wirausaha Muda Mandiri. Jakarta: PT Gramedia Pustaka Utama.

Nugroho, Riant. 2009. Memahami latar Belakang Pemikiran Entrepreneurship Ciputra.Jakarta: PT Elex Media Komputindo.

Wijatno, Serian.2009.PengantarEntrepreneurship. Jakarta: PT Grasindo, Gramedia.

\section{Pustaka Laman:}

h t t p : / c n nindonesia.com/gay a hidup/20150204122713-269-29555/ barry-kusuma-dan-kisah-idealismefotografer-travel/, diakses pada 3 Agustus 2016, 11.03 WIB

h t tp://entrepreneur.bisnis.com/ $\mathrm{read} / 20120304 / 88 / 67018 / \mathrm{jumlah}$ wirausaha-ri-naik-jadi-1-56-percent, diakses pada 5 Agustus 2016, 22.13 WIB ht tp: //bisniskeuangan.kompas.com/ read/2016/03/30/192821726/Menggenjot. Jumlah.Ideal.Pelaku.Wirausaha.Indonesia, diakses pada 5 Agustus 2016, 19.40 WIB

http://haji.tempo.co/konten_berita/profil_ bisnis/2015/01/20/636151/10-NasihatGoblok-Versi-Bob-Sadino, diakses pada 29 Agustus 2016, 10.27 WIB

http://perfilman.perpusnas.go.id/kliping_artikel/ detail/408, diakses pada 12 Agustus 2016, 11.56 WIB 